\title{
Routing in Opportunistic Networks: Implementation and Research Challenges
}

\author{
Rahul Sachdeva* and Amita Dev** \\ * USICT, Guru Gobind Singh Indraprastha University, New Delhi, India \\ ** Indira Gandhi Delhi Technical University for Women, Kashmere Gate, Delhi, India \\ *Corresponding Author : rahulsachdeva9333@gmail.com
}

\begin{abstract}
Opportunistic Networks can be defined as Delay Tolerant Network, which are formed dynamically with participating nodes' help. Opportunistic Networks follows Store-Carry-Forward principle to deliver/route the data in the network. Routing in Opportunistic Network starts with the Seed Node (Source Node) which delivers the data with the help of Intermediate nodes. Intermediate nodes store the data while roaming in the network until it comes in contact with appropriate forwarding node (relay node) or destination node itself. An extensive literature survey is performed to analyse various routing protocols defined for Opportunistic Network. With mobility induced routing, establishing and maintaining the routing path is a major challenge. Further, Store-Carry-Forward routing paradigm imposes various challenges while implementing and executing the network. Due to the unavailability of the suitable relay node, data needs to be stored within the Node's Memory, imposes buffer storage issues at the node level. Also, uncontrolled flooding may impose link-level Congestion and treated as overhead to maintain the network. Another major challenge can be maintaining the energy level of the nodes in the network. Recently developed ONE (Opportunistic Network Environment) Simulator is used to simulate and emulate the environment required by Opportunistic Network. Along with the extensive literature survey of the protocols, few of the existing protocols viz. Direct Delivery, ProPHET, Epidemic and Spray \& Wait Routing are implemented using ONE Simulator to analyse their performance while in execution. Results are being compared, and the researchers' future direction is identified to address the open problems and challenges in Opportunistic Network.
\end{abstract}

Keywords: Network; Opportunistic; ONE simulator; OppNets; Routing.

\section{INTRODUCTION}

With recent advancements in technology, especially in wireless technologies, communication has only become more accessible and faster but much reliable and secure than earlier. Shifting from fixed infrastructure network to infrastructure-less provided many new opportunities to build communication networks even to remote areas with geographical challenges. Communication systems are now available in remote areas, but cost compared with wired networks is reduced and had network access for all. To overcome and various challenges imposed by traditional wireless networks, a different approach is introduced as Opportunistic Networks (OppNets) (Trifunovic et al., 2017).

OppNets can be explained as Delay Tolerant Networks (DTNs), which can deliver data with an acceptable delay. Further, OppNets can be classified as a particular class of Mobile Adhoc Networks (MANETs) (Abusalah et al., 2008) in which end to end path is established opportunistically between source and destination in case of unavailability of any path. In contrast, in DTNs, end to end path is established before data transmission from source to the destination node. When compared with MANETs, the difference lies in the knowledge of the network. Nodes in MANETs are 
fully periodically updated with the network topology, and routes are well established between the source and the destination. When compared with OppNets, participating nodes knows their immediate neighbours only, and if there exists no route/relay agent, intermediate nodes store the data with it. A network hierarchy is represented in Figure 1, bases upon infrastructure requirement and delivery approach. In Single Hop Network, the source node delivers data directly to the destination node, whereas in Multi-Hop Network, the source node delivers data with intermediate/relay nodes' help.

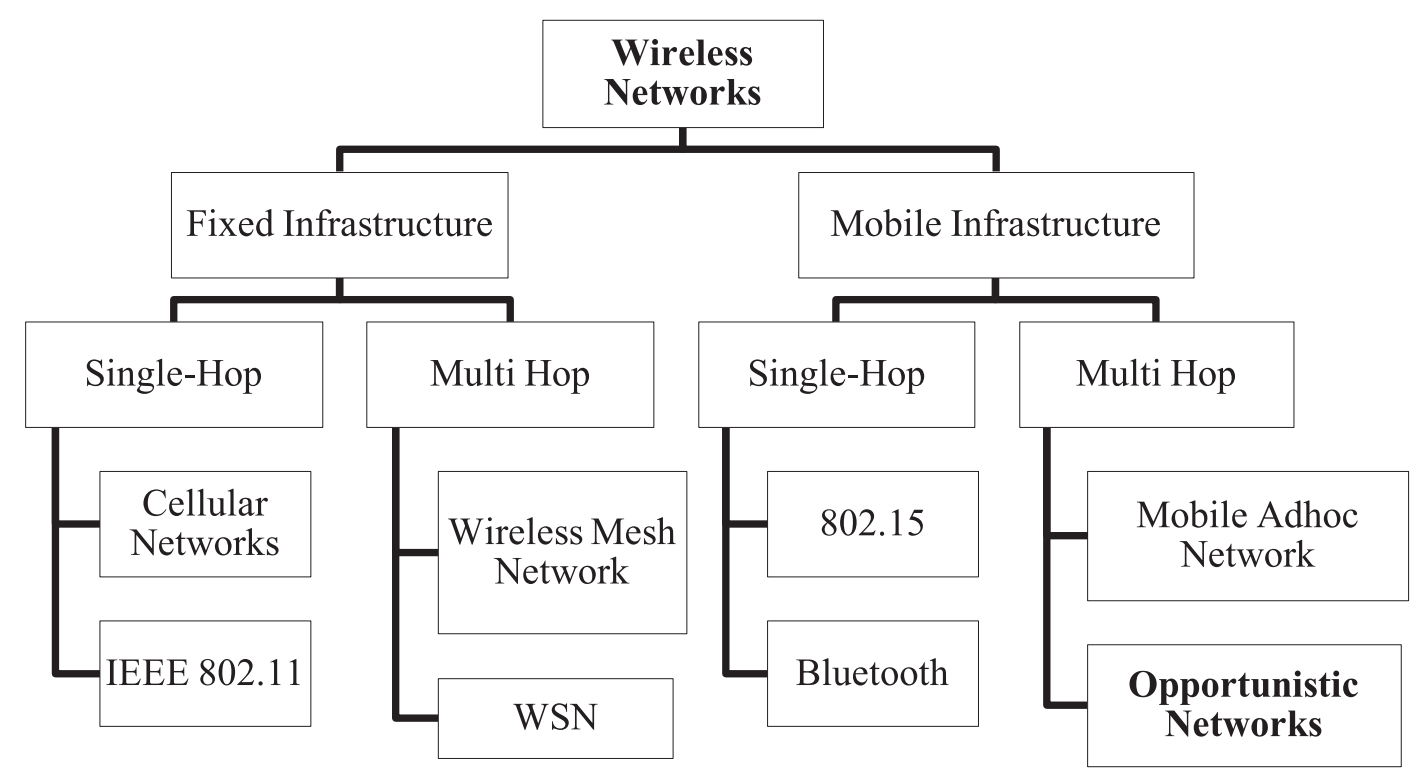

Figure 1. Hierarchy for Wireless Networks based on their requirement of Infrastructure

\section{OPPORTUNISTIC NETWORKS}

Opportunistic Networks (OppNets) are challenged Mobile Adhoc Network further with unpredictable \& dynamic topology and long disconnections in the network. OppNets constitute the category MANETs where diverse; nodes are not engaged full time but are admitted in the network dynamically to accomplish specific tasks they have been called to participate. OppNets aims to utilise its resources by admitting foreign nodes/networks to expand the network. Figure 2 explains the concept of mobility induced routing in OppNets.
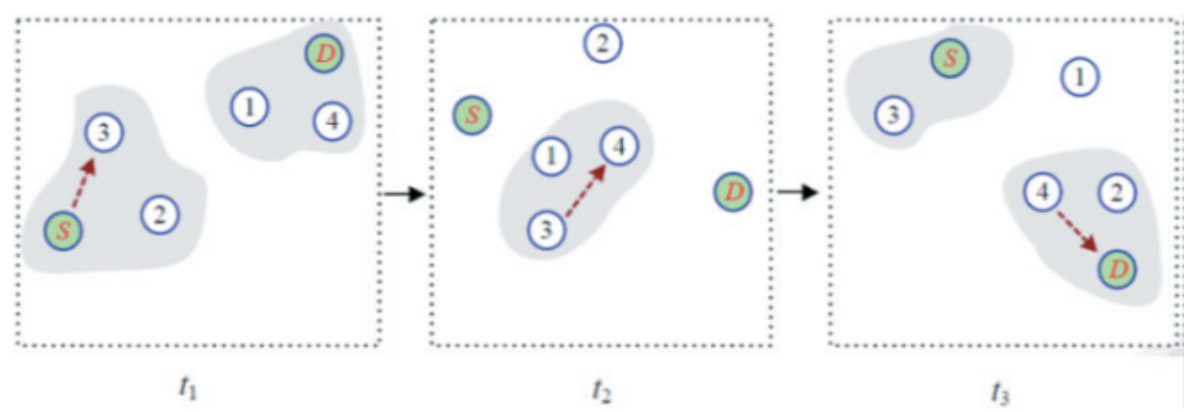

Figure 2. Mobility Induced Communication in OppNets 
Architecture: OppNets starts with the seed node (initial node/source node in the network), which may not have the fixed infrastructure or enough resources to communicate. OppNets are not equipped with a fixed network size or prefixed network topology. OppNets may allow foreign nodes to participate in the network to expand the network. These nodes may be distinguished from each other but must follows store-carry-forward routing.

Figure 3 depicts the layered architecture implementing store-carry-forward routing paradigm through the extra layer in OppNets known as "Bundle Later" (Huang et al., 2008).

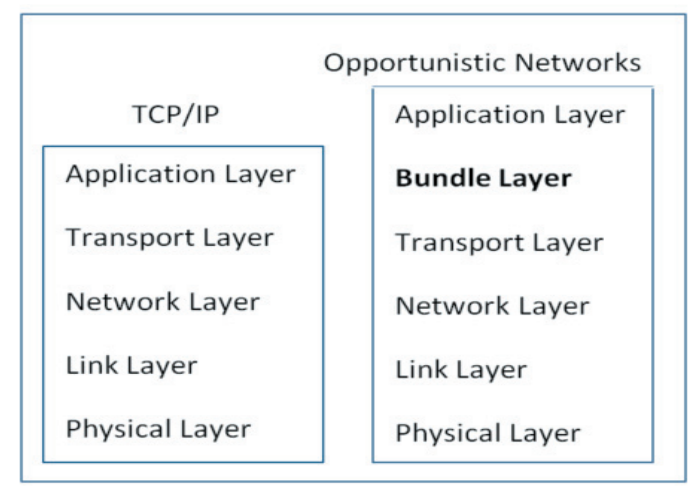

Figure 3. Layered Architecture comparison for TCP/IP \& Opportunistic Networks

\section{ROUTING IN OPPORTUNISTIC NETWORK}

As communication in OppNets depends upon the availability of infrastructure and further on the cooperation of the nodes in the network, routing protocols for the network are divided based on their infrastructure needs (Abdelkader et al., 2016). Further, depending upon their routing principle, they are categories under various subsections. Figure 4 gives an overview of the hierarchy of routing protocols in OppNets.

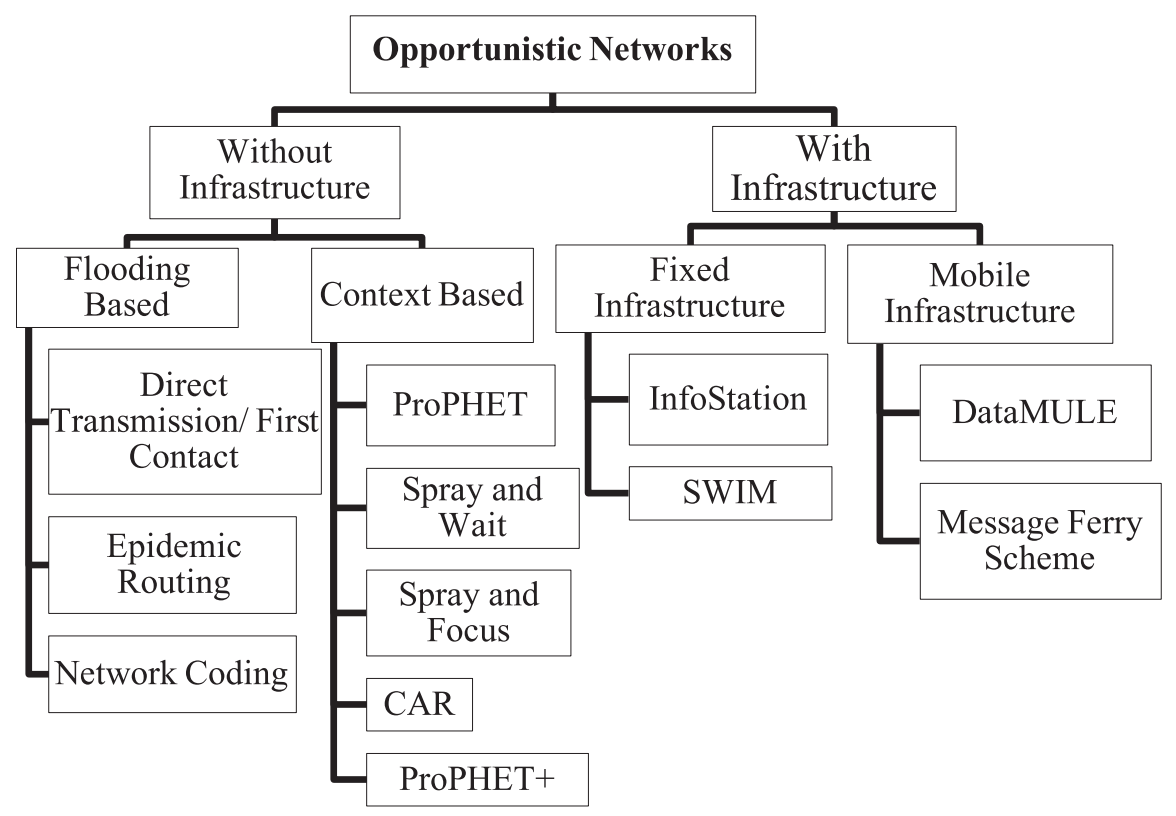

Figure 4. Routing Protocols in OppNets 
Routing in OppNets (Flooding Based): Primary routing approach can be to forward the data to deliver within the network to every participating node. Multiple copies of the same data packet can be made and forward to the neighbours among participating nodes. The process is repeated within the network until data is successfully transmitted to the final destination node. Flooding based approach are further categorised as Controlled and Uncontrolled Flooding. In uncontrolled Flooding, the most common approach is the Epidemic Routing Protocol. There is no limit on the number of copies of the data packet flooded in the network. Another approach can be the First Contact, in which the data packet is forwarded to the first node which comes in the range. Whereas Direct Transmission, source nodes store the data while waiting for the destination node to comes in the direct transmission range.

Context-Based Protocols for Routing OppNets: Though uncontrolled flooding provided better opportunities to deliver the network's data packet, it imposed a higher overhead in the network. Uncontrolled flooding can be improved by combining context information such as encounter history, available storage of node, energy levels etc., to select the next relay/intermediate node. Various routing protocols based upon controlled/uncontrolled flooding are discussed in Table 1.

Table 1. Infrastructure-less Routing Algorithms in Opportunistic Networks

\begin{tabular}{|c|c|c|c|c|c|c|}
\hline \multirow[b]{2}{*}{$\begin{array}{l}\text { Routing } \\
\text { Protocol }\end{array}$} & \multirow[b]{2}{*}{ Routing Approach } & \multirow[b]{2}{*}{$\begin{array}{c}\text { Assumptions } \\
\text { (if stated) }\end{array}$} & \multicolumn{2}{|c|}{ Algorithm } & \multirow[b]{2}{*}{ Remarks } & \multirow[b]{2}{*}{$\begin{array}{l}\text { Simulator } \\
\text { Used (when } \\
\text { proposed) }\end{array}$} \\
\hline & & & $\begin{array}{l}\text { Copies } \\
\text { Made of the } \\
\text { Data Packet }\end{array}$ & $\begin{array}{l}\text { Next Hop/ } \\
\text { Relay Agent } \\
\text { Selection }\end{array}$ & & \\
\hline $\begin{array}{c}\text { Direct } \\
\text { Delivery } \\
\text { (Spyropoulos } \\
\text { et al., 2004) }\end{array}$ & $\begin{array}{l}\text { The source node keeps the } \\
\text { packet in its storage until it can } \\
\text { forward directly to destination } \\
\text { node only }\end{array}$ & $\begin{array}{l}\text { Restricted } \\
\text { Memory } \\
\text { Buffer Size }\end{array}$ & Single & $\begin{array}{l}\text { Destination } \\
\text { Node }\end{array}$ & $\begin{array}{l}\text { High } \\
\text { Transmission } \\
\text { delay can } \\
\text { be there due } \\
\text { to no fixed } \\
\text { topology/ } \\
\text { contact }\end{array}$ & $\begin{array}{l}\text { Custom } \\
\text { Discrete } \\
\text { Event Java } \\
\text { Based } \\
\text { Simulator }\end{array}$ \\
\hline $\begin{array}{l}\text { First Contact } \\
\text { (Jain et al., } \\
\text { 2004) }\end{array}$ & $\begin{array}{l}\text { Node carrying the data packet } \\
\text { forwards to the first node it } \\
\text { comes in contact with. }\end{array}$ & $\begin{array}{c}\text { Not } \\
\text { Mentioned }\end{array}$ & Single & $\begin{array}{l}\text { Next node in } \\
\text { range }\end{array}$ & $\begin{array}{l}\text { Looping } \\
\text { problem and } \\
\text { High Delay }\end{array}$ & $\begin{array}{l}\text { Own DTN } \\
\text { Simulator }\end{array}$ \\
\hline $\begin{array}{l}\text { Epidemic } \\
\text { (Vahdat et } \\
\text { al., 2000) }\end{array}$ & $\begin{array}{l}\text { Uncontrolled flooding in the } \\
\text { network makes unlimited copies } \\
\text { of the data packet and floods } \\
\text { to neighbouring nodes until } \\
\text { delivered to the destination. }\end{array}$ & $\begin{array}{l}\text { Limited } \\
\text { Memory } \\
\text { Buffer Size }\end{array}$ & Unlimited & Flooding & $\begin{array}{l}\text { High } \\
\text { resource } \\
\text { utilization }\end{array}$ & Monarch \\
\hline $\begin{array}{l}\text { Network } \\
\text { Coding } \\
\text { (Lin et al., } \\
\text { 2007) }\end{array}$ & $\begin{array}{l}\text { The epidemic Routing approach } \\
\text { is further optimised to limit the } \\
\text { number of packet being flooded } \\
\text { by finding the appropriate } \\
\text { routing. Network coding is } \\
\text { implemented for relay nodes to } \\
\text { optimise overall performance. }\end{array}$ & $\begin{array}{l}\text { Sufficient } \\
\text { Memory } \\
\text { Buffer } \\
\text { available }\end{array}$ & Limited & Flooding & $\begin{array}{c}\text { Destination } \\
\text { node must } \\
\text { wait until all } \\
\text { packets are } \\
\text { not received } \\
\text { to start } \\
\text { decoding } \\
\text { the packets } \\
\text { through } \\
\text { various } \\
\text { routes. }\end{array}$ & $\begin{array}{l}\text { Custom } \\
\text { Discrete } \\
\text { Event Java } \\
\text { Based } \\
\text { Simulator }\end{array}$ \\
\hline
\end{tabular}




\begin{tabular}{|c|c|c|c|c|c|c|}
\hline $\begin{array}{l}\text { ProPHET } \\
\text { (Lindgren et } \\
\text { al., 2003) }\end{array}$ & $\begin{array}{l}\text { To optimise forwarding in the } \\
\text { network, the forwarder node } \\
\text { can be selected based on its } \\
\text { probability of delivery based } \\
\text { upon previous encounters. }\end{array}$ & $\begin{array}{l}\text { Limited } \\
\text { Buffer } \\
\text { (Memory) } \\
\text { Size }\end{array}$ & Single & $\begin{array}{l}\text { Probability } \\
\text { based upon } \\
\text { the previous } \\
\text { instances }\end{array}$ & $\begin{array}{c}\text { Overhead of } \\
\text { probability } \\
\text { calculation at } \\
\text { each node }\end{array}$ & $\begin{array}{l}\text { Custom } \\
\text { Simulator }\end{array}$ \\
\hline $\begin{array}{l}\text { Spray and } \\
\text { Wait } \\
\text { (Spyropoulos } \\
\text { et al., 2005) }\end{array}$ & $\begin{array}{l}\text { Routing principle is divided } \\
\text { into two phases. Firstly in } \\
\text { spray phase, fixed number } \\
\text { of copies of data packet are } \\
\text { flooded to neighbouring nodes } \\
\text { in range. It then shifts to the } \\
\text { wait phase, where the node } \\
\text { carrying the data packet waits } \\
\text { to come in the direct range of } \\
\text { the destination node. }\end{array}$ & $\begin{array}{l}\text { Sufficient } \\
\text { Memory } \\
\text { Buffer } \\
\text { available }\end{array}$ & Limited & Randomly & $\begin{array}{l}\text { Decision } \\
\text { making is } \\
\text { Random }\end{array}$ & $\begin{array}{c}\text { Own } \\
\text { Simulator }\end{array}$ \\
\hline $\begin{array}{l}\text { Spray and } \\
\text { Focus } \\
\text { (Spyropoulos } \\
\text { et al., 2007) }\end{array}$ & $\begin{array}{l}\text { Approach work in a similar } \\
\text { manner as Spray and Wait. } \\
\text { However, in the Spray phase, } \\
\text { along with the data packet, a } \\
\text { token is forwarded and nodes } \\
\text { with the token can only make } \\
\text { copies of the data packet. } \\
\text { Other, as in Wait Phase, waits } \\
\text { for the destination node. }\end{array}$ & $\begin{array}{l}\text { Sufficient } \\
\text { Buffer } \\
\text { available }\end{array}$ & Limited & $\begin{array}{l}\text { Timer Based } \\
\text { Flooding }\end{array}$ & $\begin{array}{c}\text { High } \\
\text { resource } \\
\text { consumption }\end{array}$ & $\begin{array}{c}\text { Own } \\
\text { Simulator }\end{array}$ \\
\hline $\begin{array}{c}\text { CAR } \\
\text { (Musolesi } \\
\& \text { Mascolo, } \\
\text { 2009) }\end{array}$ & $\begin{array}{l}\text { To enhance the process of } \\
\text { selecting of forwarding node, } \\
\text { context information can be } \\
\text { used. Further, the author has } \\
\text { used Utility theory for Kalman } \\
\text { Filter Based Prediction methods } \\
\text { for delivery probability } \\
\text { prediction. }\end{array}$ & $\begin{array}{l}\text { Sufficient } \\
\text { Memory } \\
\text { Buffer } \\
\text { available }\end{array}$ & Single & $\begin{array}{l}\text { Based upon } \\
\text { the Utility } \\
\text { Theory } \\
\text { Function } \\
\text { implemented } \\
\text { using } \\
\text { Kalman } \\
\text { Filter }\end{array}$ & $\begin{array}{l}\text { Routes } \\
\text { needs to be } \\
\text { re-initiated } \\
\text { every } \\
\text { time when } \\
\text { required. No } \\
\text { history is } \\
\text { stored in the } \\
\text { network. }\end{array}$ & OMNET++ \\
\hline $\begin{array}{l}\text { ProPHET+ } \\
\text { (Huang et } \\
\text { al., 2010) }\end{array}$ & $\begin{array}{l}\text { ProPHET approach is } \\
\text { further optimised here with } \\
\text { the inclusion of context } \\
\text { information such as battery } \\
\text { power, buffer storage available } \\
\text { with node, bandwidth } \\
\text { limitation, etc. }\end{array}$ & $\begin{array}{l}\text { Sufficient } \\
\text { Memory } \\
\text { Buffer } \\
\text { available }\end{array}$ & Single & $\begin{array}{c}\text { Node having } \\
\text { the highest } \\
\text { delivery } \\
\text { probability }\end{array}$ & $\begin{array}{l}\text { Collecting } \\
\text { and } \\
\text { processing } \\
\text { context } \\
\text { information } \\
\text { may } \\
\text { overload the } \\
\text { network. }\end{array}$ & $\begin{array}{c}\text { NS-2/ } \\
\text { DTNSIM }\end{array}$ \\
\hline $\begin{array}{c}\text { HiBOp } \\
\text { (Boldrini et } \\
\text { al., 2007) }\end{array}$ & $\begin{array}{l}\text { Identity Tables are maintained } \\
\text { to store the routing information } \\
\text { based upon the nodes' } \\
\text { encounter history for making a } \\
\text { routing decision. }\end{array}$ & $\begin{array}{l}\text { Managed } \\
\text { and Limited } \\
\text { Memory } \\
\text { Buffer Size }\end{array}$ & Single & $\begin{array}{l}\text { Bases upon } \\
\text { Identity } \\
\text { Tables Made. }\end{array}$ & $\begin{array}{c}\text { Overhead of } \\
\text { maintaining } \\
\text { the Identity } \\
\text { Tables. }\end{array}$ & $\begin{array}{c}\text { Own } \\
\text { Simulator }\end{array}$ \\
\hline
\end{tabular}


Fixed-Infrastructure Routing Protocols for OppNets: Infrastructure support, whether fixed or mobile, can be utilised to forward the message. Depending upon the routing principle, adequate infrastructure support can be installed for communication. It should be taken care that the infrastructure used should have high computing support for energy and storage. Base stations are formed at optimal locations (can be fixed/ or mobile), used as a Gateway/Relay agent to forward the data packet further to intended nodes. Sources Node stores the packet with itself till it comes in direct contact be any of the base stations, which can further relay the message. There are mainly two algorithms defined for such routing scheme:

- InfoStation Model (David et al., 1997): Fixed Base Stations, known as InfoStations, acts as Gateways to accomplish the communication between mobile nodes. InfoStations are capable of handling high bandwidth intense communication and are always ready for communication. Source Node can forward data to InfoStation which then becomes Base Station responsibility to deliver to the destination.

- Shared Wireless InfoStation Model (SWIM) (Small \& Haas, 2003): Based upon InfoStation Model by supporting multihop communication in the network. The nodes, can drop data packet to Base Station (InfoStation) directly or in a multihop fashion, with intermediate nodes' help. When compared with the InfoStation Model, the delay is significantly reduced as per simulation.

\section{Mobile-Infrastructure Protocols for Routing in OppNets:}

Few nodes in the network are embedded with fixed infrastructure, which acts as Mobile Data Collectors to regularise communication. These nodes move on their predetermined path and can receive or deliver data to different nodes in their range while travelling. These nodes can be called Mobile Ubiquitous LAN Extensions (MULEs), Carriers or Ferries. Two powerful algorithms based on the approach are given below:

- Data-MULE (Jain et al., 2006): This is a three-layer architecture model for delivering the data in Wireless Sensor Networks (WSNs).

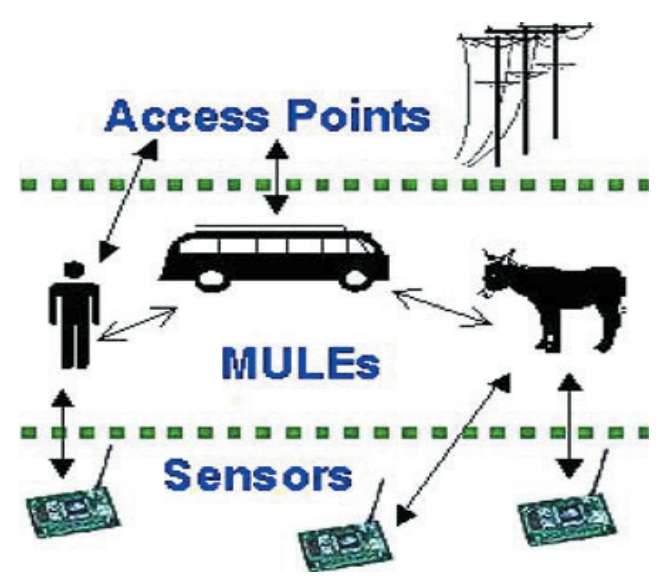

Figure 5. Concept of Data-MULE

Figure 5 shows the architecture model for Data-MULEs. Lower Layer or Sensor Layer consists of sensor nodes that sense and collects the data in the network. Middle Layer consists of MULEs which further collects data from the sensors. MULEs can freely roam in the network to communicate with other nodes. Top Layer consists of the Data repositories for collection of data/information collected from the MULEs. 
- Message Ferrying Approach (Zhao et al., 2004): In this model, concept of Message Ferrying is introduced, which acts as Data Relay Agent to facilitate communication. This model can be defined as a mobility induced network where these Ferries can roam freely in the network and collect or deliver the data.

\section{RESEARCH CHALLENGES}

- Opportunistic Networks are currently seen as an open issue for researchers to contribute to various fields. For researchers, many opportunities are there to propose algorithms to optimize the performance of the OppNets and mitigate numerous challenges faced in communication.. A few of the open-ended challenges are listed below based upon the study performed:

- Identification of Forwarded Node/Relay Agent: As already discussed, communication in OppNets depends upon foreign nodes' participation in the network. Identifying approximate forwarding node is still an open challenge in the OppNets. Node identification algorithm can be generated for the appropriate selection of the next forwarded node.

- Intra-Network Communication: Communication between the participating nodes can help in optimizing network efficiency. Context information such as battery power, mobility traces, and contact history may play a vital role in selecting the relay agent, thus improving the network's overall routing performance.

- Deliverance of Nodes: Once Communication in completed in the OppNets, participating nodes are released from the network. This helps nodes clear their memories related to communication and ready for the subsequent communication in the row. The algorithm can be proposed to initiate such measures to free up nodes as soon as the communication is completed.

- Energy Constraints (Lu \& Hui, 2010): Most devices participating in the communications are battery-powered handheld devices. Optimizing battery power will further help in extending the overall network lifetime.

- Optimize Network Overhead: Routing in Opportunistic Networks mainly depends upon finding the opportunistic contacts based upon the information being flooded in the network. However, flooding imposes high overhead on the network. Again with the help of context information, routing algorithms can be optimized to reduce the network's overhead.

- Storage Management (Viren et al., 2012; Wang et al., 2014; Seligman et al., 2007; Poonguzharselvi \& Vetriselvi, 2012; Gaoy et al., 2012): As routing in Opportunistic Network depends upon store-carry-forward paradigm, the node's storage is important for accomplishing communication in the network. Node's storage should be utilized in such a manner; it can carry/forward more data packets to improve the overall network efficiency.

\section{IMPLEMENTATION OF OPPORTUNISTIC NETWORK}

Compared with the Traditional Wireless approached, OppNets distinguish itself from them in terms of the Network's knowledge and how communication is being performed in the network, i.e. data forwarding and processing approaches. The store-carry-forward paradigm of routing makes it impossible to simulate such type of Networks on the conventional simulator. 


\section{Tools Available for Implementing OppNets:}

\section{ONE (Opportunistic Network Environment) Simulator (Keränen, 2008):}

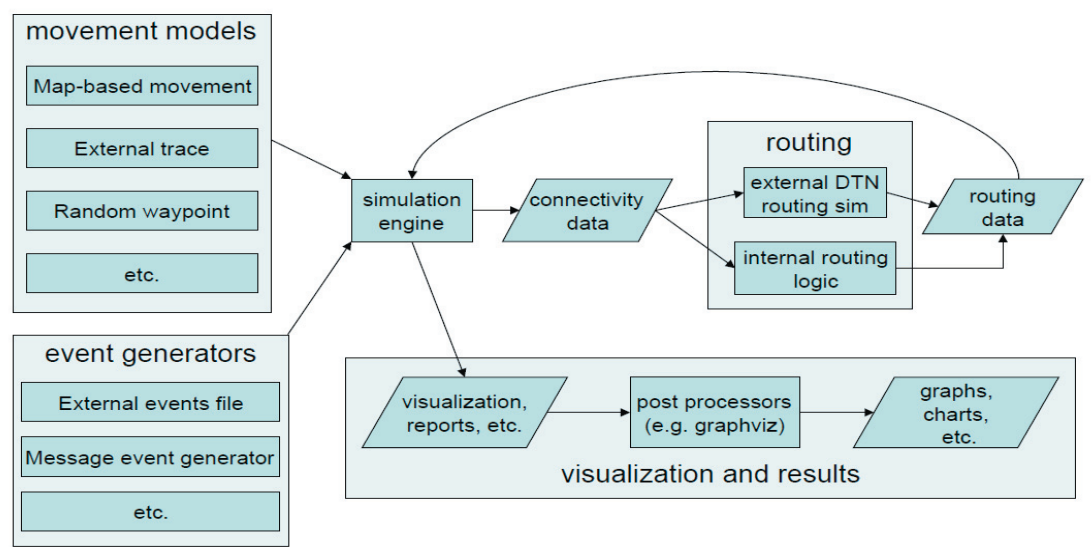

Figure 6. ONE Simulator Working Process

ONE Simulator is explicitly designed for OppNets to act as a discrete-event generator. ONE Simulator is partitioned in various parts to accomplish simulation for OppNets. Figure 6 gives an overview of various modules of the ONE Simulator. Major responsibly of the ONE simulator are node movement modelling, forming inter-node contacts, performing routing in the network and handling the messages. Various real-life inspired Mobility models are defined in the network. Further, results are collected for analysed using visualization and post-processing tools.

OMNET++ (Helgason, 2008): OMNET++ extends the supports for simulating and implementing IP protocols for OppNets with INET Framework's help. It is a C++ based simulator that further acts discrete event generator for simulating OppNets protocols with the help of the following two modules:

- Active Module: Traditional module written in $\mathrm{C}++$ only for simulating class libraries.

- Compound Module: Facilitate communication by taking care of the connection state between the nodes

NS-3 (Riley \& Henderson, 2010): Network Simulator 3 is open-source software that can act as a discrete event generator to simulate. For implementing OppNets, it provide support for the various Mobility Models, Network Traffic Management, Data Processing and and link-level analysis. Various external libraries can be imported to work along with inbuilt modules to extend the support for OppNets. Further, for visualisation Network Animator can be used.

\section{APPLICATIONS OF OPPORTUNISTIC NETWORKS}

Opportunistic Networks are mobility induced wireless network. Communication is made possible opportunistically and network is deployed by admitting distinct nodes roaming in the neighbourhood. OppNets, due to its store-carryforward paradigm, can offer various new applications of the wireless networks:

ZebraNet (Martonosi, 2004): Princeton University has implemented a wireless Mobile Sensor Network based upon OppNets to study and track Zebra's movement in the Central Kenya (region of Savanna). A P2P network is formed with robust sensors to monitor the mobility traces of the Zebras. 
Shared Wireless InfoStation Model (Small \& Haas, 2003): It is similar to ZebraNet, but is implemented for blue whales to study their movement and behaviour.

Underwater Sensor Network (UWSN): To study aquatic animal and other coral reefs, UWSN (Chandrasekhar et al., 2006) is deployed to understand various environmental issues. Based upon TDMA, a sensor network is deployed underwater where robots roam around the sensors to collects the data from sensors and further deliver to processing unit for analysis.

Emergency Response Systems: In OppNets, communication starts with the source node (seed node), which further admits various distinct nodes in the network to grow and forward the information. This type of architecture is highly beneficial for emergencies where there is a need for immediate network deployment to broadcast the recuse information.

Internet Access to Rural Areas: OppNets, due to its lower cost of deployment, can be deployed in areas with less population with comparatively less cost to traditional networks.

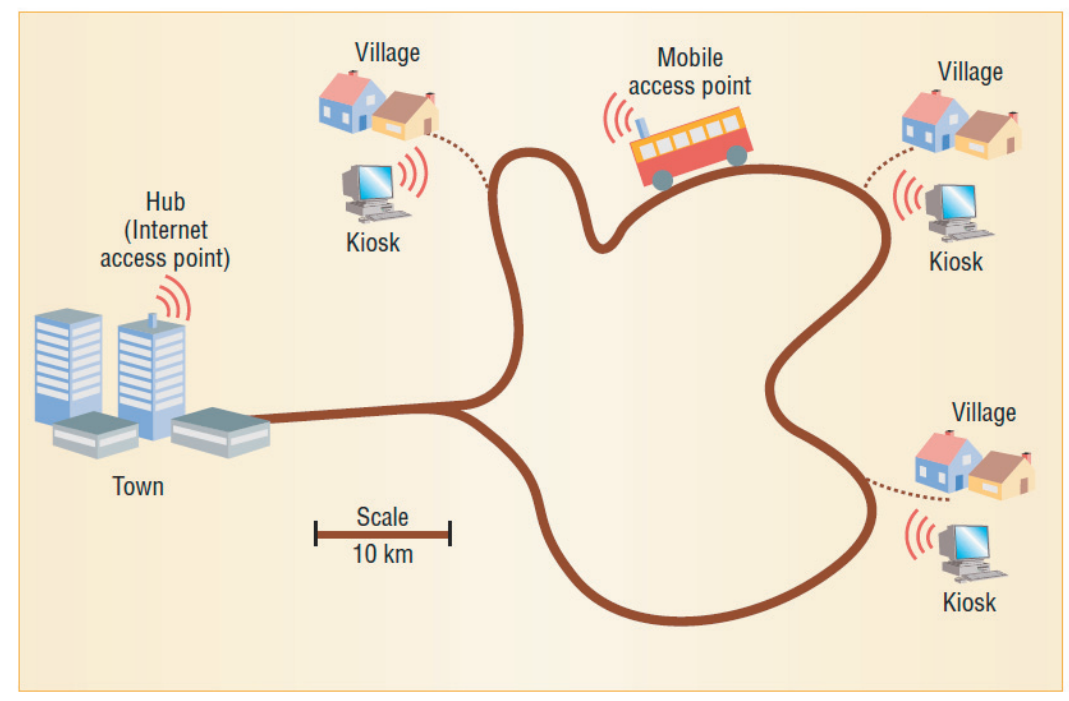

Figure 7. DakNet Concept

One such project is deployed in India, known as DakNet (Pentland et al., 2004). Figure 7 gives a snapshot of the concept. It is installed in some regions of India by MIT Media Lab in association with IIT.

\section{CONCLUSION AND FUTURE SCOPE}

The paper aims to serve as elementary material to the new researchers in the field. Opportunistic Networks are the fast-growing open-ended network for researchers to work upon. Due to its acceptance for dynamic topology and fast initialization approach, OppNets are being considered for various real-life applications, as discussed in the paper. Further, many routing protocols are proposed for the OppNets, but none of them can fully overcome the network's challenges. Based on the study, it is concluded that history information plays a vital role in optimizing the delivery in the network. In Future, the hybrid routing approach can be developed by utilizing history information with the nodes' context information to optimize the routing in the network. 


\section{REFERENCES}

Abdelkader, T., Naik, K., Nayak, A., Goel, N., \& Srivastava, V. 2016. A performance comparison of delay-tolerant network routing protocols. IEEE Network, 30(2): 46-53.

Abusalah, L., Khokhar, A., \& Guizani, M. 2008. A survey of secure mobile Ad Hoc routing protocols. IEEE Communications Surveys \& Tutorials, 10(4): 78-93. Quarter Four 2008

Boldrini, C., Conti, M., Jacopini, J., \& Passarella, A. 2007. HiBOp: a History Based Routing Protocol for Opportunistic Networks. 2007 IEEE International Symposium on a World of Wireless, Mobile and Multimedia Networks. doi:10.1109/wowmom.2007.4351716

Chandrasekhar, V., Seah, W. K., Choo, Y. S., \& Ee, H. V. 2006. Localization in underwater sensor networks: survey and challenges. In Proceedings of the 1st ACM international workshop on Underwater networks, 33-40

Gaoy Z., Zhuy H., Duy S., Xiaoy C. \& Luz R. 2012. PMDS: A Probabilistic Misbehavior Detection Scheme in DTN. In Proceedings of IEEE International Conference on Communications (ICC) : 4970-4974.

Goodman, D. J., Borras J., Mandayam N. B. \& Yates R.D. 1997. INFOSTATIONS: A New System Model for Data and Messaging Services. IEEE Vehicular Technology Conference 1997 (VTC'97), 2: 969-973.

Helgason, Ó. R., \& Jónsson, K. V.2008. Opportunistic networking in OMNeT++. In Proceedings of the 1st international conference on Simulation tools and techniques for communications, networks and systems \& workshops (p. 82). ICST (Institute for Computer Sciences, Social-Informatics and Telecommunications Engineering)

Huang, C. M., Lan, K., \& Tsai, C.-Z. 2008. A Survey of Opportunistic Networks. 22nd International Conference on Advanced Information Networking and Applications - Workshops (AINA Workshops, 2008).

Huang, T.-K., Lee, C.-K., \& Chen, L.-J. 2010. PRoPHET+: An Adaptive PRoPHET-Based Routing Protocol for Opportunistic Network. 2010 24th IEEE International Conference on Advanced Information Networking and Applications.

Jain S., Shah R. C., Bbrunette W., Borriello G. \& Roy S. 2006. Exploiting Mobility for Energy Efficient Data Collection in Wireless Sensor Networks," ACM/Kluwer Mobile Networks and Applications (MONET), 11(3): $327-339$.

Jain, S., Fall, K., \& Patra, R. 2004. Routing in a delay tolerant network. Proceedings of the 2004. Conference on Applications, Technologies, Architectures, and Protocols for Computer Communications - SIGCOMM '04.

Keränen, A. 2008. Opportunistic Network Environment Simulator. Special Assignment report, Helsinki University of Technology, Department of Communications and Networking.

Lin, Y., Liang, B., \& Li, B. 2007. Performance modeling of network coding in epidemic routing. Proceedings of the 1st International MobiSys Workshop on Mobile Opportunistic Networking - MobiOpp '07.

Lindgren, A., Doria, A., \& Schelén, O. 2003. Probabilistic routing in intermittently connected networks. ACM SIGMOBILE Mobile Computing and Communications Review, 7(3) : 19-20.

Lu X., Hui P. 2010. An Energy-Efficient n-Epidemic Routing Protocol for Delay Tolerant Networks. 2010 IEEE Fifth International Conference on Networking, Architecture, and Storage, Print ISBN: 978-1-4244-8133-0

Martonosi, M. 2004. The Princeton ZebraNet Project: Sensor Networks for Wildlife Tracking. Princeton University: $2-7$.

Musolesi, M., \& Mascolo, C. 2009. CAR: Context-Aware Adaptive Routing for Delay-Tolerant Mobile Networks. IEEE Transactions on Mobile Computing, 8(2): 246-260. doi:10.1109/tmc.2008.107 
Patel V. G., Oza T. K., Gohil D. M. 2012, Vibrant Energy Aware Spray and Wait Routing in Delay Tolerant Network. Journal of Telematics and Informatics (JTI) 1(1): 43-47 ,ISSN: 2303-3703

Pentland, A., Fletcher, R., \& Hasson, A. 2004. DakNet: rethinking connectivity in developing nations. Computer, 37(1): 78-83.

Poonguzharselvi B., Vetriselvi V. 2012. Trust Framework for Data Forwarding in Opportunistic Networks using Mobile Traces. International Journal of Wireless \& Mobile Networks (IJWMN), 4(6): 115-126.

Riley, G. F., \& Henderson, T. R. 2010. The ns-3 network simulator. In Modeling and tools for network simulation. Springer, Berlin, Heidelberg : 15-34

Seligman M., Fall K., Mundur P. 2007. Storage Routing for DTN Congestion Control, Wireless Communications and Mobile Computing, 7(10): 1183-1196.

Small T. \& Haas Z. J., 2003. The Shared Wireless Infostation Model - A New Ad Hoc Networking Paradigm (or Where There is a Whale, there is a Way), Proc. 4th ACM Int'l. Symp. Mobile Ad Hoc Networking and Computing (MobiHoc), Annapolis, MD.

Spyropoulos, T., Psounis, K., \& Raghavendra, C. S. (n.d.). 2004. Single-copy routing in intermittently connected mobile networks. First Annual IEEE Communications Society Conference on Sensor and Ad Hoc Communications and Networks, 2004. IEEE SECON 2004.

Spyropoulos, T., Psounis, K., \& Raghavendra, C. S. 2005. Spray and wait. Proceedings of the 2005 ACM SIGCOMM Workshop on Delay-Tolerant Networking-WDTN' 05.

Spyropoulos, T., Psounis, K., \& Raghavendra, C. S. 2007. Spray and Focus: Efficient Mobility-Assisted Routing for Heterogeneous and Correlated Mobility. Fifth Annual IEEE International Conference on Pervasive Computing and Communications Workshops (PerComW'07).

Trifunovic, S., Kouyoumdjieva, S. T., Distl, B., Pajevic, L., Karlsson, G., \& Plattner, B. 2017. A Decade of Research in Opportunistic Networks: Challenges, Relevance, and Future Directions. IEEE Communications Magazine, 55(1): 168-173.

Vahdat, A., Becker, D. Epidemic Routing for Partially Connected Ad Hoc Netw. 2000. Technical Report CS 200006 2000, Department of Computer Science, Duke University, NC. Available online: http:/citeseerx.ist.psu. edu/viewdoc/summary?doi=10.1.1.34.6151 (accessed on 25 Sept. 2019)

Wang B., Hu Y., Liang H., Lin Q., Shi Y., Wang X. 2014. Congestion Control Strategy Based on Probability Selection in Delay Tolerant Mobile Sensor Network. Journal of Information \& Computational Science, September 20, ISSN: $1548-7741$.

Zhao W., Ammar M., \& Zegura E. 2004. A Message Ferrying Approach for Data Delivery in Sparse Mobile Ad Hoc Networks. Proceedings of 5th ACM Int'l. Symp. Mobile Ad Hoc Networking and Computing (MobiHoc '04), ACM Press, Tokyo, Japan :187-198. 